\title{
Domestic urban water rate structure and water prices in Mallorca, Balearic Islands
}

Estructura de precios del agua de abastecimiento urbano doméstico en Mallorca, Islas Baleares

\author{
Angela Hof \\ angela.hof@sbg.ac.at \\ Department of Geography and Geology \\ University of Salzburg (Germany) \\ Macià Blázquez-Salom \\ mblazquez@uib.cat \\ Departament de Geografia \\ Universitat de les Illes Balears (Spain) \\ Joana Maria Garau \\ jgarau@dgreghid.caib.es \\ Direcció General de Recursos Hídrics \\ Conselleria de Medi Ambient, Agricultura i Pesca \\ Govern de les Illes Balears (Spain)
}

\begin{abstract}
Water rate structures were analysed to assess water prices per unit of water consumed in the domestic urban sector. Water prices and variability are set in spatial context and patterns are analysed on the background of municipal urban and tourist profiles. In addition, scenario calculations reveal that the block rate is not sufficiently progressive and prices are too low, in particular where low density housing with lawns and swimming pools dominates. Finally, we look at
\end{abstract}


the institutional framework for establishing water prices and for managing water resources more sustainably.

Key words: water price variability; transparency; water consumption; institutional framework.

\section{Resumen}

Se analizan las estructuras tarifarias del abastecimiento de agua de consumo urbano doméstico, para evaluar sus precios. Dichos precios y su variabilidad se contextualizan espacialmente y sus patrones son analizados para perfiles municipales urbanos y turísticos. Los escenarios revelan que los bloques tarifarios no son suficientemente progresivos y que los precios son bajos, particularmente en urbanizaciones extensiva, con dominio de jardines y piscinas. Finalmente, analizamos el marco institucional para establecer los precios del agua y hacer una gestión de los recursos más sostenible.

Palabras clave: variabilidad de los precios del agua; transparencia; consumo de agua; marco institucional.

\section{Introduction}

Several studies have pointed out that Mediterranean Spain must face the risks and uncertainties brought about by its water-dependent urbanization models, including residential tourism, for urban water demand and supply management (Hof \& Wolf, 2014; Morote et al., 2017; Parés et al., 2013).

In the Spanish coastal areas and the Balearic Islands, the trend of urban and socio-economic growth is exerting a particularly strong pressure on water resources. Urban and demographic growth has been identified as the most significant expressions of the process of socio-economic tourist modernization in Spain (Mantecón, 2010). The demand for water appears to be rising inexorably due to the combined effects of urban and tourist growth. More disperse, low density urban landscapes evolve that are characterized by a spacious residential matrix with large plots occupied by gardens and swimming pools (Domene \& Saurí, 2006; Morote \& Hernández, 2016; Parés et al., 2013; Vidal et al., 2010). As a result, urban water uses have a growing share of total water demand, which now is up to $10 \%$ (2002) with the residential sector consuming $70 \%$ of urban water use. Per-capita water consumption has increased since 1996 at an annual average rate of $2 \%$ and water prices increased by $4 \%$ every year over the last decade. Recreational uses (tourism, golf courses, swimming pools, second homes) are the most rapidly growing water uses (Maestu \& Gómez, 2010). As Spanish water law prioritizes urban water supply, the projections for climatically induced and increasing competition for water between the urban, tourist and agricultural sectors is foreseeable. In this context it is worth mentioning that the revenue from water uses in tourism can be 
up to 60 times higher compared to agriculture (Gössling et al., 2012), and that the financial returns of golf courses are substantially higher per unit area than those of agriculture (Rodriguez Diaz et al., 2007).

The efficient allocation of existing resources is a very important consideration for urban water demand management and planning on tourist islands and at the same time, the conflicting roles of water management, planning and water pricing are obvious. Mediterranean Islands are particularly challenged by water resources management due to their geographical isolation, their small size and the impossibility to draw on more distant or diverse aquifers. Characteristic is their dependence on natural renewable resources (groundwater and surface water, including reservoirs) and increasingly, dependence on non-conventional water resources (sea and groundwater desalination, treated wastewater).

The assessment of water management on the major Mediterranean Islands of Corsica, Crete, Cyprus, Mallorca and Sicily pointed to the importance of a responsible awareness of the agricultural, domestic, and tourism sectors of their usage of water to ensure a sustainable water management in accordance with the European Union Water Framework Directive (Donta \& Lange, 2008). The Water Framework Directive already provides a legal framework for the policy objective that all waters (surface, underground and coastal) ought to attain a good and non-deteriorating status. The new approaches and responsible awareness needed must integrate the ecological, economic and social aspects of water policy at the level of river basins. Like for the whole Mediterranean, the main objectives are to protect and improve the islands' aquatic environment and to make a contribution to sustainable, balanced and equitable water use. However, the current situation on the islands is characterized by vulnerability to extreme weather events and the projected effects of climate change. The major challenges are to meet the growing water demands, to control environmental pollution and to improve sanitation infrastructure. The recommended policy and management options have been repeatedly laid out in detail and need not be repeated here (Candela et al., 2005; Donta \& Lange, 2008). Climate change adaptation measures have been described for Mediterranean agriculture (Candela et al., 2012) and the utilization of nonconventional water sources such as desalinated seawater, treated wastewater and brackish water are discussed as means of novel approaches to sustainable water resources management (Gikas \& Angelakis, 2009; Lazarova et al., 2001). Despite significant vulnerabilities to climate change, this challenge is hardly reflected in sustainable tourism policy and planning documents (compare Dodds and Kelman, 2008, on Malta and Mallorca). Water relevant policies still adhere to the hydraulic paradigm and focus mainly on water supply enhancement, rather than water demand management.

Urban water demand management and planning has become particularly important because urban and tourist demand are increasingly blending in the course of a new water-dependent urbanization model in Mediterranean Spain (Morote et al., 2017). Spain has very low water prices, with urban 
tariffs in the lower segment of the OECD countries (Calatrava \& Garrido, 2009). Despite the fact that by 2009, implementation of the European Water Framework Directive in Spain has caused an increase of $100 \%$ in drinking water prices compared to the 2000 , the price level in Spain is still below the European average (EEA, 2013). There is a political and technical consensus that the Spanish water prices should be higher in order to internalize the full social, environmental and economic cost of its supply. The current scenario is that the public authorities are promoting the privatization of the public water supply in order to delay and translate its prices' increases to the concessionary companies' decisions (Morán, 2013; Trillas, 2013).

This research is based on data compilation of water prices in the island of Mallorca, Balearic Islands. Comparable to the coastal zone of Mediterranean Spain, Mallorca is at the same time a major tourist destination and the island exhibits urban sprawl due to the expansion of urban growth by and for tourist purposes, including residential tourism and low-density urban expansion. The magnitude of per capita water consumption and tourist accommodation per inhabitant reflects this nexus, and the information on water loss in the distribution network shows that the issue of water resources management is highly relevant in the island (Figure 1).

As a consequence of these complex socio-economic developments, urban water demand and water supply have become the most dynamic sector of water resources management (Maestu \& Gómez, 2010; March \& Saurí, 2010; Masjuan et al., 2008). An NGO, the Spanish consumer protection association FACUA carried out a survey of water prices in 28 Spanish cities and discovered great differences between the cities not only in the end user price levels, but also the rate structure. Water prices in Palma de Mallorca ranked among the top three in the analysis (FACUA, 2013).

In recent years, a rich body of literature has analyzed Spanish urban water systems, particularly dealing with: the linkages to the real estate bubble and residential tourism (Hernández et al., 2015; Hof \& Blázquez-Salom, 2015; Morote et al., 2017; Rico-Amorós et al., 2009) and the enlargement of water supply through infrastructure projects (Rico-Amorós et al., 2013), especially installation of large seawater desalination plants (Hof et al., 2014; March et al., 2014). Yet studies of urban water prices are rare and mostly concerned with the hotel tourist sector (Deyà-Tortella \& Tirado, 2011; Deyà-Tortella et al., 2016; Dinarès \& Saurí, 2015).

The lack of comprehensive and transparent overviews about the way in which water prices are set in urban-tourist contexts in Spain justifies the exploratory nature of the present research. In particular in island contexts like Mallorca, the primary function of pricing water delivered to municipal users by public water supply systems is the efficient allocation of existing resources in the short run, to adjust demand to the available supply and saving resources. Basic theory on water rate structures stresses three basic functions of water rates: First, generating revenue to cover water utility costs. Second, allocating costs among different use types and user groups. Third, send price signal to customers as 
incentives for behaviour changes. In contexts where water resources are scarce or in other ways costly, water prices should encourage customers to modify their behavior to use water more efficiently. Hence, water rates relate to demand management and planning (Hanemann, 1998; Howe, 1998).

Figure 1. Spatial pattern of per capita tourist infrastructure, per capita domestic water consumption and state of the water distribution network

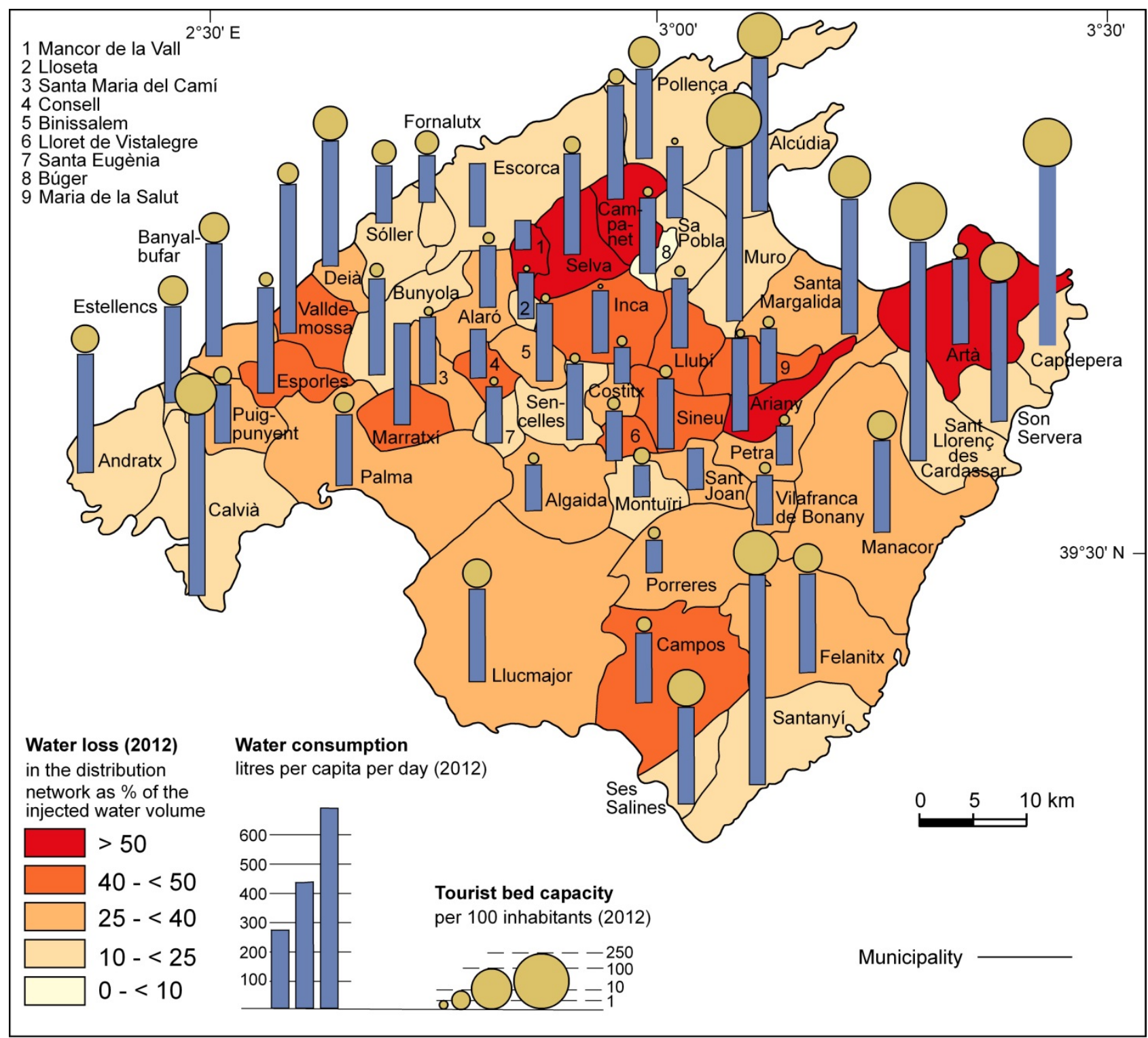

Source: authors' compilation based on IBESTAT (2012) and Govern de les Illes Balears (2012) data. Design and cartography by the authors

Hypothetically, water prices have to be directly and positively related to these factors of human pressure on the natural resources. According to the Spanish legislation, water is a public and free good. Pricing it has to reflect the way in which the public administration finances the expenses of its provision, understood as a public service; this is creating, maintaining and enhancing the water 
supply network. A progressive increase of the water prices should internalize its expenses, penalize its abusive use and serve to communicate its scarcity (compare Hanemann, 1998). Therefore, pricing can send signals to consumers and serve as incentives for a more prudent water use. But also the characteristics of the institutional framework have to be considered in establishing water pricing.

Like in other parts of Spain, water rate structures in Mallorca Island have been under reform in the last two decades. Until the year 2000, residential users in 40\% of Mallorcan municipalities had flat charges that were independent of the quantity of water used. Since then, an increasing block-rate has been introduced in $94 \%$ of the 53 municipalities. In the block-rate structure, the unit charge increases with the amount consumed. No concise information is currently offered on this topic. The Balearic Islands Official Bulletin (BOIB) publishes these data of tariffs and taxes -for each municipality, each in different moments and ways - that establishes the water prices (Govern de les Illes Balears, 2017). The Spanish legislation allows the public authorities to establish the prices of public supplied water through two different mechanisms: first, establishing tariffs with the agreement of the regional government Commission of Prices; second, via municipal councils that settle taxes. The former implies that there must be no extra gains to the payment of the strict cost of the public service.

The motivation for this research is also based on the conviction that societal challenges concerning water resources management require a broad participation and debate for which comprehensive and transparent overviews about the way in which water prices are set in urban-tourist contexts in Spain are basic information: "Transparency in how water prices are calculated is important for broad public understanding of why water prices vary as they do and are set as they are. Likewise, an understanding of water pricing will foster stakeholder participation if the opportunities for such participation are present." (EEA, 2013, p. 44)

\section{Material and methods}

\subsection{Compilation and analysis of a municipal water rate structure database}

Information on water rate structures and data on the amount paid per unit of water consumption were collected from the Official Gazette of the Balearic Islands (in Catalan: Butlletí Oficial de les Illes Balears) for each of the 53 Mallorcan municipalities. Compilation of this data was organized in a spreadsheet to provide an overview on the water rate structures (in Catalan: Tarifa) and charging schemes (in Catalan: Tarificació). All data correspond to the year 2014. These rates do not usually change for a long period of time, and are only occasionally corrected for the annual inflation rate (Deyà-Tortella et al., 2016). 
In agreement with the water prices analysis provided by FACUA / OCU (2013) and García-Rubio et al. (2015), the calculations were performed for an annual total of $175 \mathrm{~m}^{3}$ of water consumed per household and for a standard $13 \mathrm{~mm}$ pipe connection to the water distribution network. First, we calculated the domestic end user price in Euro/m³. Service and maintenance cost which are charged on an annual basis were included. This annual total is divided by the annual consumption to obtain the average price per unit of water consumed that is comparable for all the municipalities that charge monthly.

If water rate structures are designed to meet the three basic functions outlined above, it can be expected that certain patterns will be discernible when comparing prices among municipalities and that differences and changes in the urban-tourist model could be related to urban water rates. Therefore, to discern a pattern in pricing policy, this analysis looks at correlation metrics for combinations of a) magnitude of price differentials in the block rate, b) urban water prices and total or per capita urban water supply, c) long-term changes in these two variables, d) hotel tourist intensity per capita, e) municipal population change and f) second home ownership rates and water prices in the municipalities that charge monthly.

\subsection{Comparative analysis of water price and annual water bills for two typical residential and seasonally varying water consumption patterns}

Mallorca is a major Mediterranean tourist destination and it is hard to find urban areas that have not any tourist accommodation use. For the comparison of two major residential urban models on the island, two submunicipal areas and their respective monthly water consumption patterns have been selected. These two submunicipal districts of Calvià represent high and low density residential areas with important differences in housing typologies: parcel size, lawn area and presence of swimming pools (Hof and Schmitt, 2011). As empirical evidence shows that indoor residential water demand is inelastic but total residential water demand depends on such housing characteristics (Deyà-Tortella et al., 2017), the two areas are used for a scenario calculation. For this purpose, the monthly per capita consumption figures for the two cases are averaged over three years and used to comparatively calculate the average price per unit of water consumed and the annual water bill this water use behavior would incur if it took place across the municipalities with monthly charging schemes and increasing block rates. Each of the two scenarios is calculated for each of the municipalities and submunicipal districts that apply monthly water charges. In addition, the final price is compared with and without service and maintenance charge. This calculation reflects the observed temporal and quantitative pattern of residential water consumption. The scenario calculations are based on real water rates and tariffs, observed and realistic monthly use patterns and summed up to an annual total. This way, the results reveal the price range that is difficult to grasp when looking at the water rates and magnitude of price differentials themselves. 
The interrelationships of water consumption patterns and urban land use patterns have been analysed in previous research with elaborated water consumption analysis on a per capita basis (Hof \& Schmitt, 2011). The results on water consumption patterns in Mallorca (Hof \& Schmitt, 2011) are used here for a scenario calculation that compares the annual water bill that would result for the typical low density residential urban model that has developed all over the island in the last two decades versus the more compact, high-density residential model typical for Mediterranean Spain and Mallorcan settlements.

Nova Santa Ponsa and El Toro are located in Calvià municipality in the Costa de Palma-Calvià area in the southwest of the island. Both submunicipal districts have a number of flats and apartments in multi-residential houses that are used by tourists and also a couple of hundred hotels beds. However, only 3.3\% of the official tourist bed capacity in Calvià municipality is concentrated in Nova Santa Ponsa, Costa de la Calma and El Toro. Yet the proportion of non-Spanish residents, an indicator of second home ownership, is over $50 \%$ here (2011). Nova Santa Ponsa is a typical example of the low density second home urban model with irrigated landscaping, where 88\% of all parcels are used by single residential houses. The garden area accounts for $18 \%$ of the parcel and $77 \%$ of the parcels have a swimming pool. El Toro is a relatively high density residential area which hosts only one hotel and has a share of $96 \%$ single residential houses. The garden areas accounts for $21 \%$ of the parcels and $37 \%$ of the parcels have a swimming pool. Parcels are smaller in El Toro than in Nova Santa Ponsa. Residential water consumption profiles show that throughout the year, more water is consumed per area in Nova Santa Ponsa compared to El Toro (Figure 2). The lowest difference in average monthly consumption (2005-2007) occurs in January (1.1 times higher) and the maximum difference (1.7 times more $\mathrm{m}^{3}$ per hectare) in August. Distinct seasonal effects occur in both residential settlements. The mean ratio of summer versus winter water consumption (20052007) is evidence of a seasonal pattern of water consumption and is 1.6 in Nova Santa Ponsa and 1.2 in El Toro. In summer (May to September), on average 1.6 times more water is consumed per area in Nova Santa Ponsa when compared to El Toro. The higher water consumption is related to the larger areas of pools, lawn and garden maintained compared to the high density settlement. 
Figure 2. Residential water consumption profiles

for two urban-tourist models in absolute volume and per area

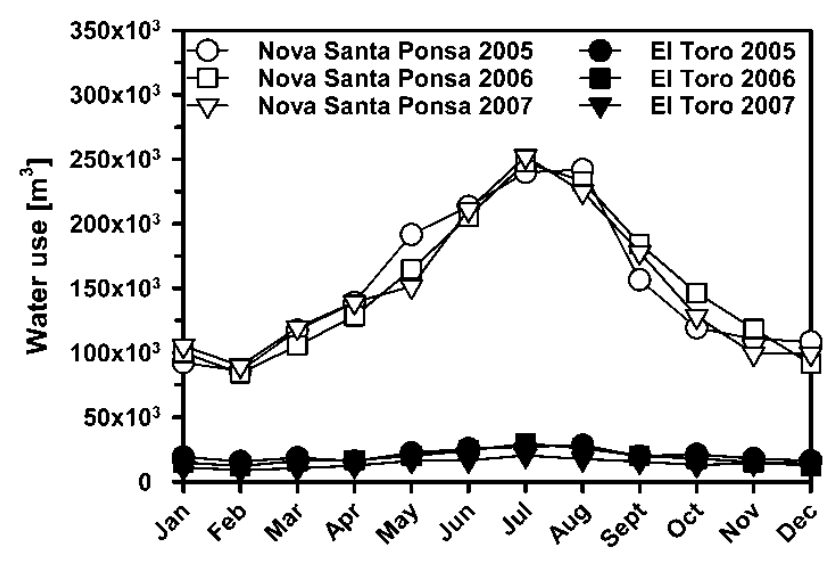

Month

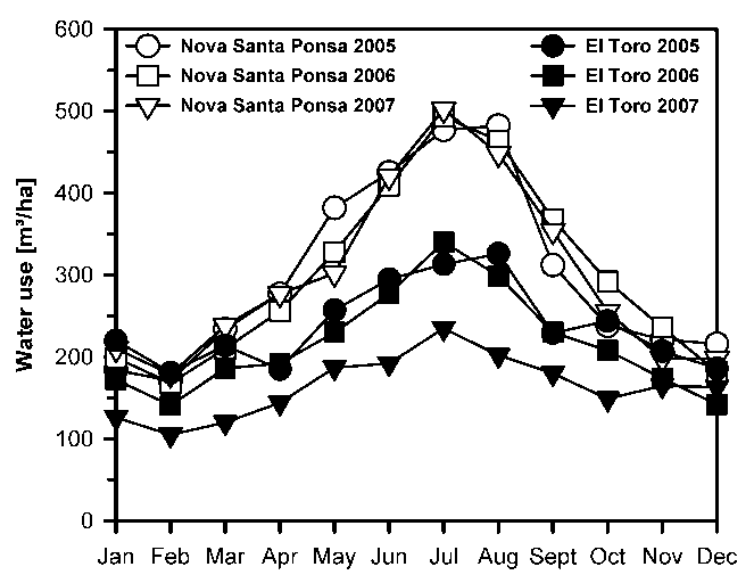

Month

Source: authors' compilation of water consumption data

\section{Results and discussion}

\subsection{Water rate structures in Mallorcan municipalities}

The analysis of the Official Gazette of the Balearic Islands showed that for the 53 municipalities, altogether 66 domestic urban water rate structures are in effect. Overall, the water rate system combines a fixed charge (quota de servei) with a variable one that has a multiblock tariff or flat rate. In most of the municipalities, domestic water consumption has its own prices, different from tourist accommodation, shops, industrial, etc. Most of the pricing schemes follow progressive tariffs. Many buildings have only one counter, this makes that many different houses could use it and therefore sum up their consumption, resulting in a progressive increase of the water price. In order to solve it, and not punishing these consumers, some municipalities divide the consumption among the number of homes before applying the progressive tariffs. This is the case, for instance, of Artà's municipal regulations in 2014.

The spatial pattern of the water rate structure and water prices in municipalities and submunicipal areas with a monthly charging scheme is shown in Figure 3.

Eight coastal municipalities have a different rate structure for submunicipal areas, among which there are some major hotel tourism areas. Rates that are based on flat charges which are entirely independent of the quantity of water used are the exception and in effect in 11 cases. 
Figure 3: Spatial pattern of the water rate structure and water prices in Mallorca

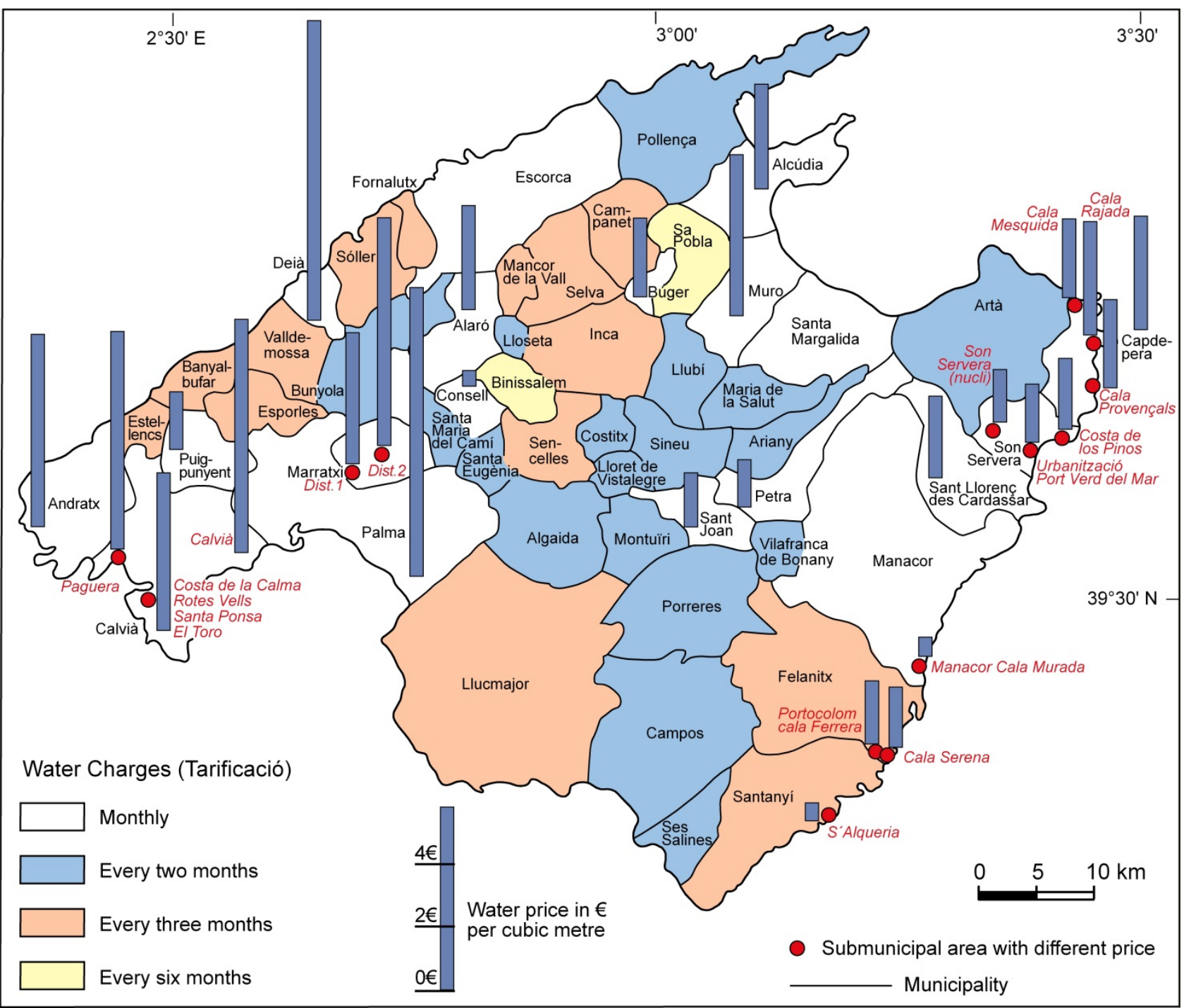

Source: authors' elaboration. Design and cartography by the authors

For the areas with a monthly charging scheme, the lower block switch points is at $10 \mathrm{~m}^{3}$ in 16 cases and at $20 \mathrm{~m}^{3}$ in 10 cases, meaning that the majority of municipalities charge the lowest per unit price for water consumption amounts of up to 80 and up to 161 litres per capita per day (lpd), respectively, if one thinks of a typical single-family household with four people. At an average and median water consumption of 220 lpd and 178 lpd in Mallorca (2012), these switch points are therefore mostly at a level too low for most households to attain without a very substantial change in household water use. The magnitude of price differentials between the blocks indicates that the municipalities that charge monthly or every two months are targeting consumption at the high end of the range of consumption (Table 1).

A more detailed result is given when looking at the magnitude of price differentials between the first and second block for the municipalities that charge monthly and have a switch point of $20 \mathrm{~m}^{3}$ as upper limit for the second block rate. In this group, 14 municipalities have a price differential of up 
to $50 \%$ between the first and second block rate, while 8 municipalities have a price differential of up to $100 \%$. Son Severa (nucli) charges twice as much and Deià even seven times as much in the second block. These results are discussed in the following by considering the logic and rationale behind the principles for pricing water delivered to municipal users by public water supply systems (Hanemann, 1998).

Theoretically, a high price differential between the first and second block of the increasing block rate, as well as a high magnitude of price differentials between the highest and lowest block rate, has the potential to provide price signals to customers as incentives for them to use water efficiently, and to generate revenue that permits the water utility to cover its costs. Analyzing the correlation between the total volume of urban water consumption in these municipalities or their total urban water consumption per capita and the magnitude of price differentials reveals that it is slightly positive only for the correlation between the price differential between the third and second bloc and the total volume of urban water consumption in the municipality. This can be interpreted as a mechanism that embeds the long-run marginal cost in the higher block rates, while all other block rates are designed to generate enough revenue to at least let the utility covers its costs. So the lower block rates and the second and third block rates are designed to charge higher prices for higher consumption, but only the highest block rate is sending a strong price signal about the scarcity of water to customers. While the theoretical expectation is that the demand in the high blocks is more elastic than demand in the low blocks, this outcome is not manifest in the water consumption pattern of these municipalities. If the block rates were designed with a strong price incentive to customers in mind, one would expect that the third block had a high price differential. However, only Deià and Palma municipalities are charging steeply increasing prices despite having moderate to low per capita water consumption patterns among those municipalities with monthly charges and increasing block rates. Alcúdia is consistently doubling the price across its four equally sized block rates, as if the change in cost per unit sold would increment linearly with increase in quantity sold. A rate structure like this is in line with increasing long-run average costs the urban water industry is facing, especially if investment projects for enhanced water supply are necessary. However, this ignores economies of scale and the fact that water utility's costs are fixed to a large part in the short run and costs do not vary with the amount of water delivered.

Of the 20 municipalities that charge every two months, 10 municipalities have an increasing block rate with three blocks and identical switch points. Santa Eugènia municipality has a flat charge of $0.39 €$ for any consumption up to $16,000 \mathrm{~m}^{3}$ per year and Lloseta municipality has six blocks with different switch points. The three block rate structure has a magnitude of price differential of $100 \%$ and between the blocks, the price differential is $2.3 \%$ and $57.4 \%$. With switch points at $15 \mathrm{~m}^{3}$ and $30 \mathrm{~m}^{3}$ meters, this scheme can be expected to charge most households of 4 persons with higher than $30 \mathrm{~m}^{3}(468 \mathrm{lpd})$ consumption the highest price, but only twice as much as in the lowest block 
and irrespective of the amount. This rate structure is giving a strong price incentive to consume less than $15 \mathrm{~m}^{3}$ per month $(234 \mathrm{lpd})$ but no incentive to consume less water if more than $30 \mathrm{~m}^{3}$ are consumed at a flat charge of $1,59 € / \mathrm{m}^{3}$. Lloseta municipality charges between $0.55 €$ and $1.24 € / \mathrm{m}^{3}$ in the first three blocks with switch points at 10, 20 and $30 \mathrm{~m}^{3}$ (a 125\% price differential) and then with decreasing magnitudes of price differentials for three blocks and a maximum 580\% price differential between the first and 6th block. This fine-tuned rate scheme sends a strong price signal to consumption rates above $312 \mathrm{lpd}, 468 \mathrm{lpd}$ and $625 \mathrm{lpd}$, and for any amount consumed above $781 \mathrm{lpd}\left(50 \mathrm{~m}^{3}\right)$ a flat charge of $3.74 € / \mathrm{m}^{3}$ applies. For these 12 municipalities there is a high and positive correlation (0.76) between end user price and long-term change in per capita consumption (2000-2012).

Within the group of municipalities that charge every two months, in 8 cases, rate structures (bimestral) are very heterogeneous with regard to switch points, block numbers and magnitude of price differentials. The two municipalities with the highest per capita consumption, Bunyola and Ses Salinas and an increase in long-term (2000-2012) changes in urban water consumption have switch points of 60 and $40 \mathrm{~m}^{3}$ in the first block. Bunyola charges $81 \%$ more for any consumption above $121 \mathrm{~m}^{3}$, thus the municipality is sending not a strong price incentive to consumption exceeding $504 \mathrm{lpd}$ pricing it at $0.92 € / \mathrm{m}^{3}$. Ses Salines is charging $130.8 \%$ more for any consumption exceeding $806 \mathrm{lpd}$ which is charged at $1.20 € / \mathrm{m}^{3}$.

In the group of 16 municipalities that charge every three months (trimestral), there are 4 municipalities with the steepest price increase in the second block and all others have the steepest price increase in the third or higher block. Selva and Esporles have a relatively high magnitude of price differentials (660\%-700\%) with Fornalutx having the second highest on the island (3407\%, Deià has the highest with $4650 \%$ ), yet with $14.73 € / \mathrm{m}^{3}$ in its seventh block the highest price per cubic metre on the island, Deià charges $4.75 € / \mathrm{m}^{3}$.

The two municipalities with charges being incurred every six months have identical switch points and numbers of blocks and very similar magnitude of price differentials, yet what is striking is the moderate increase over the second and third block in Binissalem with a sharp price increase for consumption above $200 \mathrm{~m}^{3}$ or $268 \mathrm{lpd}$ (the 4th block). The price charged for consumption above $200 \mathrm{~m}^{3}$ or $268 \mathrm{lpd}$ is $2.63 € / \mathrm{m}^{3}$ and $2.43 € / \mathrm{m}^{3}$ in Binissalem and Sa Pobla, respectively.

From the detailed discussion of the water rates above it becomes clear that there is a general pattern of sending strong price incentives only to very high end consumers, but there are some municipalities with very fine tuned block structures and very large magnitude of price differentials between lowest and highest blocks or the highest and second highest blocks. In other words, a very prudent water consumption of $125 \mathrm{lpd}$, which is close to the Spanish national average, is rewarded. 
In reality, water rate structures are modifications of the three basic functions described above. In fact, the philosophy is that the majority of the consumers have to pay for recovering the utility costs. The prudent consumers with low consumption are rewarded with lower rates while high end consumers are being sent price signals. In the long run, the rate has to be sustainable in economic terms, too. As a result, average consumers are between second and third blocks, so they are the ones that maintain the service. Some water rates in Mallorca therefore reflect a broader set of goals that not only include revenue, but economic efficiency and the promotion of conservation.

However, the example of the every two months charging scheme clearly shows that heterogeneity in the rate structure may be related to different business models and rationales of the utility operators. Further research is needed to explore on the one hand possible causal relations with the management and risk status of groundwater bodies from which water is extracted and on the other hand, the role that desalination water supply plays.

Table 1. Diversity of urban water rate structures in Mallorca

\begin{tabular}{|c|c|c|c|c|c|}
\hline Charging scheme & $\begin{array}{l}\text { Number } \\
\text { of areas } \\
\text { with this } \\
\text { charging } \\
\text { scheme }\end{array}$ & $\begin{array}{c}\text { Number } \\
\text { of } \\
\text { blocks }\end{array}$ & $\begin{array}{c}\text { Lowest } \\
\text { switch point } \\
{\left[\mathrm{m}^{3}\right]}\end{array}$ & $\begin{array}{l}\text { Highest switch } \\
\text { point }\left[\mathrm{m}^{3}\right]\end{array}$ & $\begin{array}{c}\text { Magnitude of } \\
\text { price differentials } \\
\text { between the } \\
\text { lowest and highest } \\
\text { blocks }\end{array}$ \\
\hline Monthly (mensual) & 28 & $3-6$ & $\begin{array}{c}3 \\
\text { (range: } 22) \\
\end{array}$ & $\begin{array}{c}148 \\
\text { (range: 108) }\end{array}$ & $\begin{array}{c}33 \%-4650 \% \\
(\text { mean } 601 \%)\end{array}$ \\
\hline $\begin{array}{l}\text { Every two months } \\
\text { (Bimestral, different } \\
\text { utility operator) }\end{array}$ & 8 & $3-8$ & $\begin{array}{c}15 \\
\text { (range: 25) }\end{array}$ & $\begin{array}{l}200 \\
\text { (range: } 40 \text { ) }\end{array}$ & $\begin{array}{c}50 \%-300 \% \\
\text { (mean 157\%) }\end{array}$ \\
\hline $\begin{array}{l}\text { Every two months } \\
\text { (Bimestral, same utility } \\
\text { operator) }\end{array}$ & 12 & $3-6$ & 15 & $\begin{array}{c}50 \\
\text { (range: } 20 \text { ) }\end{array}$ & $\begin{array}{l}98 \%-580 \% \\
\text { (mean 142\%) }\end{array}$ \\
\hline $\begin{array}{l}\text { Every three months } \\
\text { (Trimestral) }\end{array}$ & 16 & $3-7$ & $\begin{array}{c}10 \\
\text { (range: } 50 \text { ) }\end{array}$ & $\begin{array}{c}300 \\
\text { (range: 100) }\end{array}$ & $\begin{array}{c}97 \%-3407 \% \\
\text { (mean 530\%) }\end{array}$ \\
\hline $\begin{array}{l}\text { Every six months } \\
\text { (Semestral) }\end{array}$ & 2 & 4 & 112 & 200 & $\begin{array}{c}382 \%-386 \% \\
\text { (mean 384\%) }\end{array}$ \\
\hline Sum & 66 & & & & \\
\hline
\end{tabular}

Source: authors' elaboration

\subsection{Comparative analysis of water prices}

In the last three decades, Mallorca has followed a trajectory of a water-dependent urbanization model by promoting residential tourism and golf tourism and through a rejuvenation of its hotel tourist stock. Given the challenges for urban water demand and supply management, it is reasonable to expect that these changes are reflected in the water rate structure and water prices, depending on the predominant urban and tourist model in each municipality. Previous research has shown that highest water consumption figures were found in residential tourist areas with single houses that had gardens and swimming pools. The absence of a pool and a garden results in a two to three times lower mean consumption per household, per capita and in the month of maximum 
water consumption (Deyà-Tortella et al., 2017; Hof \& Schmitt, 2011; Rico-Amoros et al., 2009). It is therefore of interest to correlate water rate structure and indicators of the type of urban and tourist model. The results show that large price differentials between the blocks and the highest and lowest blocks are positively related to the ratio of second homes to main homes (Table 2). Therefore, the water rate structure is designed to accommodate for a high number of high end consumers and it sends a price signal to them. In contrast, the magnitude of conventional tourist business, as indicated by tourist bed capacity, has no relationship with urban water rate structure (Table 2). In Spain and Mallorca, the share of hotel tourist water consumption in urban water consumption eludes official statistics because tourism itself is part and parcel of urbanity created by and for tourism (Mantecón, 2010).

Table 2. Correlation metrics for relationship between urban water rate structure and urban-tourist model

\begin{tabular}{|l|c|c|}
\hline \multicolumn{1}{|c|}{$\begin{array}{c}\text { Pearson correlation } \\
\text { coefficient }\end{array}$} & $\begin{array}{c}\text { Magnitude of price } \\
\text { differentials between } \\
1^{\text {st }} \text { and } 2^{\text {nd }} \text { block }\end{array}$ & $\begin{array}{c}\text { Magnitude of price } \\
\text { differentials between } \\
\text { highest and lowest } \\
\text { block }\end{array}$ \\
\hline $\begin{array}{l}\text { Percentage second } \\
\text { homes in relation to } \\
\text { main homes }\end{array}$ & 0.75 & 0.75 \\
\hline $\begin{array}{l}\text { Density of second } \\
\text { homes (number per } \\
\text { km²) }\end{array}$ & 0.08 & 0.18 \\
\hline $\begin{array}{l}\text { Tourist density (tourist } \\
\text { bed capacity per 100 } \\
\text { inhabitants) }\end{array}$ & 0.00 & -0.05 \\
\hline
\end{tabular}

Source: authors' elaboration

Spain, and particularly Mallorca, has been affected by the real estate and tourism bubble, characterized by the growth of the urban sprawl (Hof \& Blázquez, 2013; Murray Mas et al., 2017). This rapid urban growth has demanded the enlargement of existing and the construction of new water supply infrastructures, in particular desalination plants. The results of the Pearson correlation coefficient, for the water pricing in the analyzed municipalities, offers high scores for the total volume of urban water supply (0.57), even higher for its increase $(0.65)$ and the highest for the change in per capita consumption (0.83). The former can be explained by the increasing numbers of tourists, who are not considered in this per capita water consumption rate based only on the resident population (Table 3). These results show that the water prices reflect the long-term costs and revenue for the utility costs mainly related to enlargements of the water supply infrastructure. Moreover, the 
spatial pattern of expansion of the low density urban model, which is not exclusively, but mainly related to second home tourism and expansion of the real estate industry in Mallorca (Hof \& Blázquez, 2013), shows in the spatial pattern of the water prices (Table 3).

\section{Table 3. Correlation metrics for relationship between urban water prices, demographic indicators and urban-tourist model}

\begin{tabular}{|l|c|c|}
\hline Pearson correlation coefficient & $\begin{array}{l}\text { Water price in Euro per cubic } \\
\text { metre, with service and } \\
\text { maintenance charge }\end{array}$ & $\begin{array}{l}\text { Water price in Euro per cubic } \\
\text { metre, without service and } \\
\text { maintenance charge }\end{array}$ \\
\hline $\begin{array}{l}\text { Total volume of urban water } \\
\text { supply (subministrament d'aigua } \\
\text { en l'abastiment urba) }\end{array}$ & 0.57 & 0.12 \\
\hline $\begin{array}{l}\text { Change in total volume of urban } \\
\text { water supply (2001-2012) }\end{array}$ & 0.07 & 0.65 \\
\hline $\begin{array}{l}\text { Change in per capita water } \\
\text { consumption (2001-2012) }\end{array}$ & 0.25 & 0.83 \\
\hline $\begin{array}{l}\text { Municipal inhabitants } \\
\text { Percentage second homes in } \\
\text { relation to main homes }\end{array}$ & 0.55 & 0.12 \\
\hline $\begin{array}{l}\text { Density of second homes (number } \\
\text { per km²) }\end{array}$ & 0.41 & 0.24 \\
\hline
\end{tabular}

Source: authors' elaboration

All of these results show that the rate-making processes and the rate structure of the Mallorcan municipalities are not easily understandable. Whether looking at the correlation between water prices for urban end consumers and long-term (2000-2012) changes in urban water consumption patterns or looking at patterns between the risk status of groundwater bodies as benchmarked by the European Union's groundwater directive and municipal water prices, there is no clear pattern (Hof et al., 2014). Arguably, there is some evidence that the water rate structure and water prices promote economic efficiency, appropriate valuation of water resources and are strategically sound for covering utility costs and long-term planning. Only a full economic analysis of cost-based reasons for the block-rate structure in all municipalities could reveal if the rates for the blocks vary among customer classes in a way that every customer pays the marginal cost of service for at least some of their consumption or if the block-rate structure results in some people paying a higher price for service than others (compare Hanemann, 1998). Unless there are cost-based reasons for this, concerns about equity and environmental justice are justified. However, a full economic analysis is beyond the scope of this paper and demands further research. 
While acknowledging that public water utility rate making is a challenging task given the enormous amount of data and extensive technical analysis needed to arrive at a forward-looking scheme that promotes an appropriate valuation and conservation of water resources, it is necessary to uncover the current framework and its strengths and weaknesses before recommendations for changes are possible.

\subsection{Comparative analysis of water price and annual water bills for two typical residential water consumption patterns}

Modelling two scenarios of observed monthly water consumption shows the effects of higher and more seasonal water consumption versus lower and less seasonal consumption combined with the different increasing block rate structures and pricing in the municipalities and submunicipal districts with monthly water charges. The results substantiate the observation made in previous sections that while overall price is low, the rate structure targets for high water consumption and places a relatively higher to much higher price on this as an effect of the block rates and the construction of the service and maintenance charge. The higher coefficient of variation for the high consumption scenario is the effect of maintenance charges that increase with the volume sold. However, the high coefficients of variability for the results of the high summer water use scenario show that there is no common policy between different municipalities. For both scenarios, the results show that the municipalities have no homogeneous pricing policy (Figure 4, Table 4 and Table 5).

To the contrary, on an island with almost exclusive dependency on groundwater resources, it is surprising not to observe a clearer pattern in water prices. With service and maintenance charges included, the same water use profile costs the end user 35.8 (high consumption) and 5.5 (low consumption) times more per cubic metre if it is realized in the two municipalities with the largest price differentials, namely Bunyola and Puigpunyent (for the high consumption scenario) and Alcudia and Buger (for the low consumption scenario), see Figure 4. Without service and maintenance charges, the same water use profile costs the end user 42.4 (high consumption) and 18.3 (low consumption) times per cubic metre more if it is realized in the two municipalities with the largest price differentials, namely Bunyola and Puigpunyent (for the high consumption scenario) and Calvià (SOREA) and Andratx (for the low consumption scenario). In other words, a consumer with a more seasonal water use pattern and high summer water consumption pays a maximum of 2.8 times more per cubic metre (without service and maintenance charges) and a maximum of 1.7 times more per cubic metre (with service and maintenance charges) than a consumer with an evenly water use pattern. This comparison reflects that the water rate structure serves on the one hand to meet the utility's revenue requirements and allocates costs among users. However, the results of the scenario analysis show for 12 out of our 28 study cases that cheaper prices, as a mean of $€ / \mathrm{m} 3$, occur in the scenario of higher water consumption. In agreement with other studies, these results show that particularly in cases where housing types with high-income residential houses with lawns and 
swimming pools dominate, the block rate is not sufficiently progressive and prices are too low (DeyàTortella et al., 2017; García-Rubio et al., 2015). This is the case in Consell, without service and maintenance taxes; and including this taxes in the cases of: Calvià/Aterca/Peguera, Capdepera/Cala Rajada/Cala Provençals/Na Taconera, Consell, Marratxí/District 1 \& 2, Muro, Petra, Sant Llorenç (Figure 4).

Figure 4. Urban water prices for two different use scenarios: evenly versus high summer water use

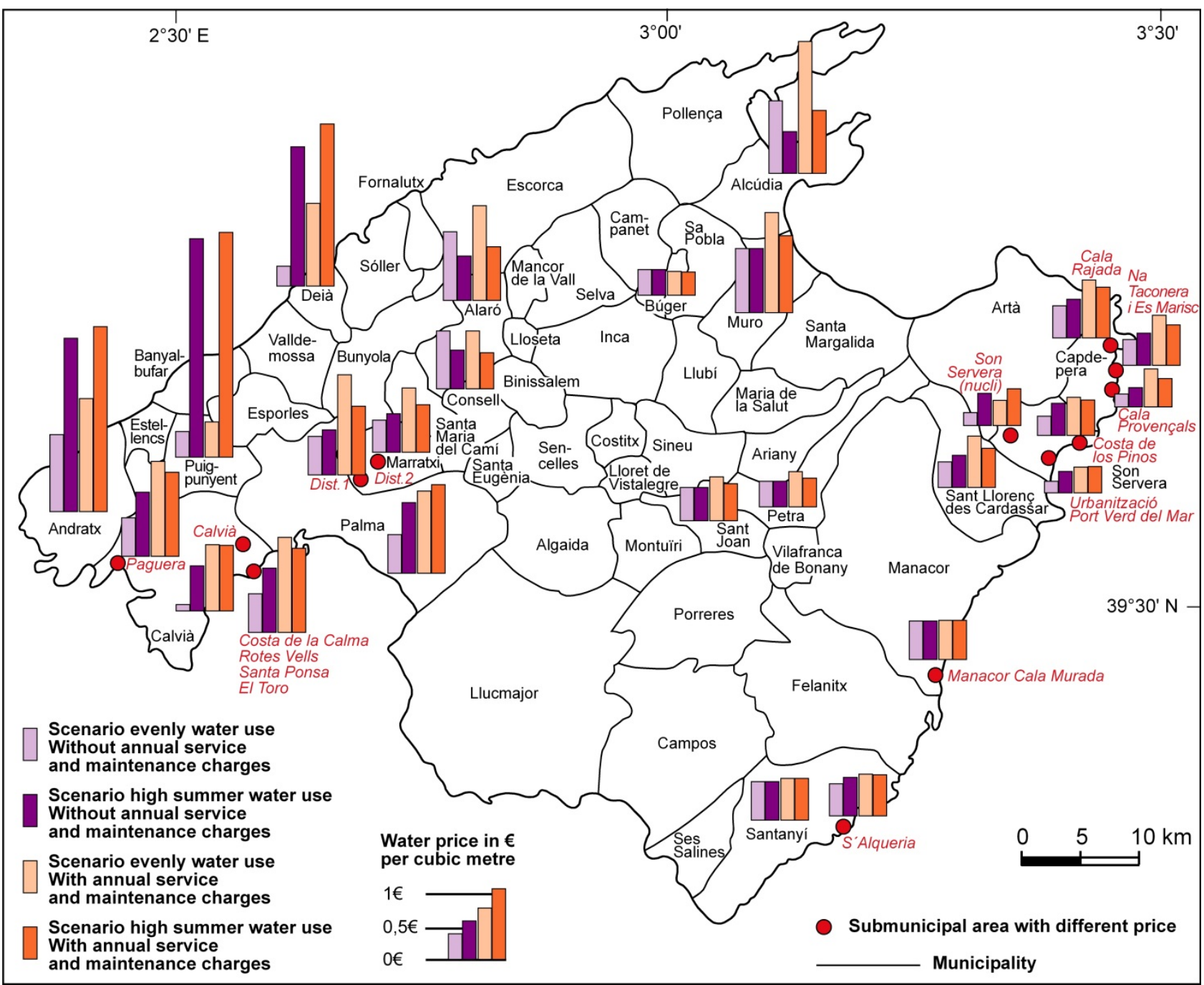

Source: authors' elaboration. Design and cartography by the authors 
Table 4. Estimation of monthly real consumption models for 28 cases of charging structures.

$\mathrm{ET}=$ evenly water use scenario; NSP = high summer water use scenario

\begin{tabular}{|c|c|c|c|c|c|c|c|c|c|c|c|c|c|c|c|c|c|}
\hline & & & January & February & March & April & May & June & July & August & September & October & November & December & & & \\
\hline $\begin{array}{c}\text { Consumption } \\
\text { models }\end{array}$ & & El Toro $(E T)\left(m^{3}\right)$ & 6.2 & 5.0 & 6.1 & 6.1 & 7.7 & 8.7 & 10.0 & 9.3 & 7.2 & 7.0 & 6.5 & 5.8 & 85.6943 & & \\
\hline & & $\begin{array}{l}\text { Nova Santa Ponsa } \\
\text { (NSP) }\left(\mathrm{m}^{3}\right) \\
\end{array}$ & 16.6 & 11.9 & 15.5 & 17.9 & 21.0 & 26.1 & 30.7 & 28.7 & 21.8 & 17.6 & 15.2 & 13.7 & 236.755 & & \\
\hline & Escenary & $\begin{array}{l}\text { Prices simulation } \\
\text { applying } \\
\text { progressive tariffs } \\
\qquad(€)\end{array}$ & & & & & & & & & & & & & $\begin{array}{l}\text { Total } \\
\text { annual } \\
\text { prices } \\
\text { with } \\
\text { quotas } \\
(€)\end{array}$ & $\begin{array}{l}\text { Price } \\
€ / \mathrm{m}^{3} \\
\text { without } \\
\text { quotas }\end{array}$ & $\begin{array}{l}\text { Price } € / \mathrm{m}^{3} \\
\text { with quotas }\end{array}$ \\
\hline Alaró & ET & Ajt (SOREA) & 5.5 & 3.9 & 5.1 & 5.9 & 6.9 & 12.7 & 15.3 & 14.2 & 7.2 & 5.8 & 5.0 & 4.5 & 126.3 & 1.07 & 1.4742 \\
\hline Alaró & NSP & Ajt (SOREA) & 8.7 & 4.8 & 7.2 & 10.3 & 14.2 & 21.9 & 32.0 & 27.6 & 15.3 & 9.9 & 6.8 & 4.8 & 197.8 & 0.69 & 0.8355 \\
\hline Alcúdia & ET & ACASA & 6.8 & 4.9 & 6.4 & 7.4 & 8.6 & 10.7 & 12.6 & 11.8 & 8.9 & 7.2 & 6.2 & 5.6 & 176.0 & 1.13 & 2.0538 \\
\hline Alcúdia & NSP & ACASA & 9.6 & 5.7 & 8.6 & 10.6 & 13.1 & 18.3 & 25.7 & 22.5 & 13.8 & 10.3 & 8.4 & 7.1 & 232.5 & 0.65 & 0.9821 \\
\hline Andratx & ET & Andratx & 6.7 & 5.1 & 6.6 & 6.5 & 8.8 & 11.3 & 15.5 & 13.4 & 8.1 & 7.8 & 7.1 & 6.2 & 151.2 & 1.20 & 1.7648 \\
\hline Andratx & NSP & Andratx & 39.2 & 21.5 & 34.2 & 44.7 & 57.8 & 80.1 & 99.6 & 91.0 & 61.3 & 43.2 & 33.0 & 26.8 & 680.4 & 2.67 & 2.8739 \\
\hline Búger & ET & Búger & 2.2 & 1.8 & 2.1 & 2.1 & 2.7 & 3.0 & 3.5 & 3.3 & 2.5 & 2.4 & 2.3 & 2.0 & 32.0 & 0.35 & 0.3733 \\
\hline Búger & NSP & Búger & 5.8 & 4.2 & 5.4 & 6.3 & 7.3 & 9.3 & 11.7 & 10.7 & 7.6 & 6.2 & 5.3 & 4.8 & 86.7 & 0.36 & 0.366 \\
\hline Bunyola & ET & $\begin{array}{c}\text { Todo el término } \\
\text { municipal }\end{array}$ & 3.1 & 2.6 & 3.1 & 3.1 & 3.9 & 4.4 & 5.1 & 4.7 & 3.7 & 3.5 & 3.3 & 3.0 & 47.0 & 0.51 & 0.549 \\
\hline Bunyola & NSP & $\begin{array}{c}\text { Todo el término } \\
\text { municipal }\end{array}$ & 1.3 & 0.8 & 1.2 & 1.4 & 1.7 & 2.2 & 2.7 & 2.5 & 1.8 & 1.4 & 1.1 & 1.0 & 22.9 & 0.08 & 0.0968 \\
\hline Calvià & ET & CALVIA SOREA & 0.0 & 0.0 & 0.0 & 0.0 & 0.2 & 1.1 & 2.5 & 1.8 & 0.0 & 0.0 & 0.0 & 0.0 & 88.2 & 0.07 & 1.0292 \\
\hline \multirow[t]{5}{*}{ Calvià } & NSP & CALVIA SOREA & 9.0 & 4.4 & 7.8 & 10.2 & 13.2 & 21.3 & 29.5 & 25.9 & 14.0 & 9.9 & 7.5 & 6.0 & 241.1 & 0.67 & 1.0184 \\
\hline & ET & Aterca SA & 4.5 & 3.6 & 4.4 & 4.4 & 5.6 & 6.6 & 8.0 & 7.3 & 5.2 & 5.0 & 4.7 & 4.2 & 113.1 & 0.74 & 1.3198 \\
\hline & NSP & Aterca SA & 14.6 & 9.9 & 13.4 & 15.8 & 18.9 & 27.0 & 35.2 & 31.6 & 19.7 & 15.5 & 13.1 & 11.6 & 275.7 & 0.96 & 1.1646 \\
\hline & ET & $\begin{array}{c}\text { Aguas de } \\
\text { Paguera SL }\end{array}$ & 3.7 & 3.0 & 3.7 & 3.6 & 4.7 & 5.8 & 7.3 & 6.6 & 4.3 & 4.2 & 3.9 & 3.5 & 126.7 & 0.63 & 1.4779 \\
\hline & NSP & $\begin{array}{c}\text { Aguas de } \\
\text { Paguera SL }\end{array}$ & 14.7 & 9.5 & 13.4 & 16.2 & 19.6 & 29.1 & 38.8 & 34.5 & 20.5 & 15.8 & 13.1 & 11.4 & 309.0 & 1.00 & 1.3051 \\
\hline
\end{tabular}


Tabla 4. Continues

\begin{tabular}{|c|c|c|c|c|c|c|c|c|c|c|c|c|c|c|c|c|c|}
\hline & & & January & February & March & April & May & June & July & August & September & October & November & December & & & \\
\hline & Escenary & $\begin{array}{l}\text { Prices simulation } \\
\text { applying } \\
\text { progressive tariffs } \\
(€)\end{array}$ & & & & & & & & & & & & & $\begin{array}{l}\text { Total } \\
\text { annual } \\
\text { prices } \\
\text { with } \\
\text { quotas } \\
(€)\end{array}$ & $\begin{array}{l}\text { Price } \\
€ / \mathrm{m}^{3} \\
\text { without } \\
\text { quotas }\end{array}$ & $\begin{array}{l}\text { Price } € / \mathrm{m}^{3} \\
\text { with quotas }\end{array}$ \\
\hline Capdepera & ET & $\begin{array}{c}\text { Capdepera y Cala } \\
\text { Rajada } \\
\end{array}$ & 3.0 & 2.4 & 3.0 & 2.9 & 3.7 & 4.2 & 4.8 & 4.5 & 3.5 & 3.4 & 3.1 & 2.8 & 77.3 & 0.48 & 0.9017 \\
\hline \multirow[t]{5}{*}{ Capdepera } & NSP & $\begin{array}{c}\text { Capdepera y Cala } \\
\text { Rajada }\end{array}$ & 9.6 & 6.2 & 8.8 & 10.6 & 12.8 & 17.4 & 23.9 & 21.0 & 13.4 & 10.3 & 8.6 & 7.5 & 186.1 & 0.63 & 0.7861 \\
\hline & ET & Cala Provençals & 1.5 & 1.2 & 1.5 & 1.5 & 1.8 & 2.1 & 2.4 & 2.2 & 1.7 & 1.7 & 1.6 & 1.4 & 50.6 & 0.24 & 0.5901 \\
\hline & NSP & Cala Provençals & 4.8 & 3.1 & 4.4 & 5.3 & 6.4 & 8.6 & 11.9 & 10.5 & 6.6 & 5.1 & 4.3 & 3.7 & 104.6 & 0.32 & 0.4419 \\
\hline & ET & $\begin{array}{c}\text { Na Taconera y Es } \\
\text { Marisc }\end{array}$ & 2.2 & 1.8 & 2.2 & 2.2 & 2.8 & 3.1 & 3.6 & 3.4 & 2.6 & 2.5 & 2.3 & 2.1 & 67.3 & 0.36 & 0.785 \\
\hline & NSP & $\begin{array}{c}\text { Na Taconera y Es } \\
\text { Marisc }\end{array}$ & 7.2 & 4.7 & 6.6 & 7.9 & 9.5 & 12.9 & 17.8 & 15.7 & 10.0 & 7.7 & 6.4 & 5.6 & 148.3 & 0.47 & 0.6266 \\
\hline Consell & ET & Urbano & 5.6 & 4.5 & 5.5 & 5.5 & 6.9 & 7.8 & 9.0 & 8.4 & 6.5 & 6.3 & 5.8 & 5.3 & 77.1 & 0.90 & 0.9 \\
\hline Consell & NSP & Urbano & 8.2 & 4.0 & 7.2 & 9.4 & 12.1 & 16.8 & 21.1 & 19.1 & 12.9 & 9.1 & 6.9 & 5.6 & 132.4 & 0.56 & 0.559 \\
\hline Deiá & ET & Deià & 1.4 & 0.5 & 1.4 & 1.4 & 2.7 & 3.4 & 4.5 & 4.0 & 2.3 & 2.1 & 1.7 & 1.2 & 110.6 & 0.31 & 1.2901 \\
\hline Deiá & NSP & Deià & 28.2 & 5.8 & 22.7 & 34.3 & 48.7 & 73.3 & 94.9 & 85.4 & 52.6 & 32.6 & 21.3 & 14.1 & 597.8 & 2.17 & 2.5249 \\
\hline Manacor & ET & $\begin{array}{c}\text { Manacor. Cala } \\
\text { Murada }\end{array}$ & 3.8 & 3.1 & 3.7 & 3.7 & 4.7 & 5.3 & 6.1 & 5.7 & 4.4 & 4.3 & 4.0 & 3.6 & 52.3 & 0.61 & 0.61 \\
\hline Manacor & NSP & $\begin{array}{c}\text { Manacor. Cala } \\
\text { Murada }\end{array}$ & 10.2 & 7.3 & 9.4 & 10.9 & 12.8 & 15.9 & 18.7 & 17.5 & 13.3 & 10.7 & 9.3 & 8.3 & 144.4 & 0.61 & 0.61 \\
\hline Marratxí & ET & $\begin{array}{c}\text { Marratxí. Distrito } \\
\text { segundo. Aguas } \\
\text { de Marratxí }\end{array}$ & 4.0 & 3.3 & 3.9 & 3.9 & 5.0 & 5.6 & 6.5 & 6.0 & 4.7 & 4.5 & 4.2 & 3.8 & 134.1 & 0.65 & 1.5651 \\
\hline Marratxí & NSP & $\begin{array}{c}\text { Marratxí. Distrito } \\
\text { segundo. Aguas } \\
\text { de Marratxí }\end{array}$ & 11.6 & 7.7 & 10.6 & 12.7 & 15.2 & 20.0 & 25.9 & 23.3 & 15.9 & 12.4 & 10.4 & 9.1 & 253.7 & 0.74 & 1.0718 \\
\hline Marratxí & ET & $\begin{array}{l}\text { Marratxí. Distrito } \\
\text { primero.Facsa }\end{array}$ & 3.0 & 2.5 & 3.0 & 3.0 & 3.8 & 4.2 & 4.9 & 4.6 & 3.5 & 3.4 & 3.2 & 2.9 & 85.7 & 0.49 & 0.9997 \\
\hline Marratxí & NSP & $\begin{array}{l}\text { Marratxí. Distrito } \\
\text { primero.Facsa }\end{array}$ & 8.8 & 5.8 & 8.1 & 9.6 & 11.5 & 15.2 & 19.6 & 17.7 & 12.0 & 9.4 & 7.9 & 6.9 & 176.4 & 0.56 & 0.7449 \\
\hline Muro & ET & Muro & 6.1 & 4.9 & 6.0 & 6.0 & 7.6 & 8.5 & 9.8 & 9.2 & 7.1 & 6.8 & 6.4 & 5.7 & 133.5 & 0.98 & 1.5583 \\
\hline Muro & NSP & Muro & 16.3 & 11.7 & 15.2 & 17.6 & 20.6 & 25.6 & 30.1 & 28.1 & 21.3 & 17.2 & 14.9 & 13.4 & 281.6 & 0.98 & 1.2 \\
\hline
\end{tabular}


Tabla 4. Continues

\begin{tabular}{|c|c|c|c|c|c|c|c|c|c|c|c|c|c|c|c|c|c|}
\hline & & & January & February & March & April & May & June & July & August & September & October & November & December & & & \\
\hline & Escenary & $\begin{array}{l}\text { Prices simulation } \\
\text { applying } \\
\text { progressive tariffs } \\
\qquad(€)\end{array}$ & & & & & & & & & & & & & $\begin{array}{l}\text { Total } \\
\text { annual } \\
\text { prices } \\
\text { with } \\
\text { quotas } \\
(€)\end{array}$ & $\begin{array}{l}\text { Price } \\
€ / \mathrm{m}^{3} \\
\text { without } \\
\text { quotas }\end{array}$ & $\begin{array}{l}\text { Price } € / \mathrm{m}^{3} \\
\text { with quotas }\end{array}$ \\
\hline $\begin{array}{l}\text { Palma de } \\
\text { Mallorca }\end{array}$ & ET & Palma & 3.8 & 2.9 & 3.7 & 3.7 & 5.0 & 5.7 & 6.8 & 6.2 & 4.6 & 4.4 & 4.0 & 3.5 & 109.5 & 0.63 & 1.2774 \\
\hline $\begin{array}{l}\text { Palma de } \\
\text { Mallorca }\end{array}$ & NSP & Palma & 15.1 & 9.2 & 13.7 & 16.7 & 22.1 & 36.5 & 49.1 & 43.6 & 24.3 & 16.3 & 13.3 & 11.4 & 326.4 & 1.15 & 1.3788 \\
\hline Petra & ET & Petra & 2.4 & 2.0 & 2.4 & 2.4 & 3.0 & 3.4 & 3.9 & 3.6 & 2.8 & 2.7 & 2.5 & 2.3 & 46.7 & 0.39 & 0.5454 \\
\hline Petra & NSP & Petra & 6.5 & 4.7 & 6.0 & 7.0 & 8.2 & 10.3 & 12.3 & 11.4 & 8.5 & 6.9 & 5.9 & 5.3 & 106.3 & 0.39 & 0.4489 \\
\hline Puigpunyent & ET & Puigpunyent & 2.39 & 1.71 & 2.35 & 2.33 & 3.31 & 3.89 & 4.71 & 4.30 & 3.02 & 2.87 & 2.58 & 2.19 & 47.9 & 0.42 & 0.5589 \\
\hline Puigpunyent & NSP & Puigpunyent & 43.91 & 8.26 & 35.12 & 53.64 & 76.76 & 115.97 & 150.40 & 135.25 & 82.87 & 51.04 & 33.01 & 21.37 & 819.9 & 3.41 & 3.4629 \\
\hline Sant Joan & ET & Sant Joan & 3.2 & 2.6 & 3.2 & 3.1 & 4.0 & 4.5 & 5.2 & 4.8 & 3.7 & 3.6 & 3.4 & 3.0 & 58.7 & 0.52 & 0.6852 \\
\hline Sant Joan & NSP & Sant Joan & 8.6 & 6.2 & 8.0 & 9.3 & 10.8 & 13.5 & 15.9 & 14.8 & 11.3 & 9.1 & 7.9 & 7.1 & 136.8 & 0.52 & 0.5778 \\
\hline Sant Llorenç & ET & $\begin{array}{l}\text { Sant Llorenç des } \\
\text { Cardassar. Son } \\
\text { Carrió. los } \\
\text { polígonos } 25,25^{a} \\
\text { y } 26 \text { de Coma y } \\
\text { complejo la } \\
\text { Buganvilla }\end{array}$ & 2.6 & 2.2 & 2.6 & 2.6 & 3.3 & 3.7 & 4.3 & 4.0 & 3.1 & 3.0 & 2.8 & 2.5 & 69.4 & 0.43 & 0.8099 \\
\hline Sant Llorenç & NSP & $\begin{array}{l}\text { Sant Llorenç des } \\
\text { Cardassar. Son } \\
\text { Carrió. los } \\
\text { polígonos } 25,25^{\text {a }} \\
\text { y } 26 \text { de Coma y } \\
\text { complejo la } \\
\text { Buganvilla } \\
\end{array}$ & 7.3 & 4.2 & 6.5 & 8.1 & 10.1 & 13.4 & 17.4 & 15.0 & 10.6 & 7.9 & 6.4 & 5.4 & 145.0 & 0.47 & 0.6123 \\
\hline Santanyí & ET & $\begin{array}{l}\text { De Cala d'Or a } \\
\text { Portopetro }\end{array}$ & 4.0 & 3.3 & 3.9 & 3.9 & 5.0 & 5.6 & 6.5 & 6.0 & 4.7 & 4.5 & 4.2 & 3.8 & 55.3 & 0.65 & 0.645 \\
\hline Santanyí & NSP & $\begin{array}{c}\text { De Cala d'Or a } \\
\text { Portopetro } \\
\end{array}$ & 10.7 & 7.7 & 10.0 & 11.6 & 13.5 & 16.9 & 19.8 & 18.5 & 14.0 & 11.3 & 9.8 & 8.8 & 152.7 & 0.65 & 0.645 \\
\hline Santanyí & ET & $\begin{array}{c}\text { S'Alqueria Blanca } \\
\text { Portopetro y Cala } \\
\text { Mondragó }\end{array}$ & 3.4 & 2.8 & 3.3 & 3.3 & 4.2 & 4.7 & 5.5 & 5.1 & 3.9 & 3.8 & 3.5 & 3.2 & 55.4 & 0.55 & 0.6465 \\
\hline
\end{tabular}


Tabla 4. Continues

\begin{tabular}{|c|c|c|c|c|c|c|c|c|c|c|c|c|c|c|c|c|c|}
\hline & & & January & February & March & April & May & June & July & August & September & October & November & December & & & \\
\hline & Escenary & $\begin{array}{l}\text { Prices simulation } \\
\text { applying } \\
\text { progressive tariffs } \\
\qquad(€)\end{array}$ & & & & & & & & & & & & & $\begin{array}{c}\text { Total } \\
\text { annual } \\
\text { prices } \\
\text { with } \\
\text { quotas } \\
(€)\end{array}$ & $\begin{array}{c}\text { Price } \\
€ / \mathrm{m}^{3} \\
\text { without } \\
\text { quotas }\end{array}$ & $\begin{array}{l}\text { Price } € / \mathrm{m}^{3} \\
\text { with quotas }\end{array}$ \\
\hline Santanyí & NSP & $\begin{array}{c}\text { S'Alqueria Blanca } \\
\text { Portopetro y Cala } \\
\text { Mondragó }\end{array}$ & 9.7 & 6.5 & 8.9 & 10.5 & 12.6 & 16.4 & 20.3 & 18.6 & 13.1 & 10.3 & 8.7 & 7.7 & 151.8 & 0.61 & 0.6413 \\
\hline Son Servera & ET & Núcleo & 1.10 & 0.65 & 1.08 & 1.06 & 1.72 & 2.11 & 2.66 & 2.38 & 1.52 & 1.43 & 1.23 & 0.97 & 33.4 & 0.21 & 0.39 \\
\hline Son Servera & NSP & Núcleo & 7.19 & 3.41 & 6.26 & 8.22 & 10.68 & 15.30 & 20.79 & 18.37 & 11.33 & 7.95 & 6.03 & 4.80 & 135.8 & 0.51 & 0.5738 \\
\hline Son Servera & ET & Costa de los Pinos & 2.04 & 1.67 & 2.02 & 2.01 & 2.54 & 2.86 & 3.31 & 3.08 & 2.38 & 2.30 & 2.14 & 1.93 & 51.0 & 0.33 & 0.5947 \\
\hline Son Servera & NSP & Costa de los Pinos & 6.6 & 3.6 & 5.9 & 7.4 & 9.3 & 13.9 & 18.2 & 16.3 & 9.8 & 7.2 & 5.7 & 4.7 & 131.3 & 0.46 & 0.5545 \\
\hline Son Servera & ET & Urb. Port Verd & 1.0 & 0.7 & 1.0 & 1.0 & 1.5 & 1.7 & 2.1 & 1.9 & 1.3 & 1.3 & 1.1 & 0.9 & 34.3 & 0.18 & 0.4008 \\
\hline Son Servera & NSP & Urb. Port Verd & 4.3 & 1.6 & 3.6 & 5.0 & 6.7 & 10.9 & 14.7 & 13.0 & 7.2 & 4.8 & 3.5 & 2.6 & 96.7 & 0.33 & 0.4085 \\
\hline
\end{tabular}

Source: authors' elaboration 
Further research is necessary to analyze to what extent the water rate structure in individual municipalities is designed to send price incentives to users with high summer water use and to what extent an impact on water use behavior is a guaranteed result. At maximum, a typical high summer water use will incur a 4.7 times higher annual bill compared to the evenly water consumption scenario (Figure 5).

Figure 5. Annual water bill for two different use scenarios: evenly versus high summer water use

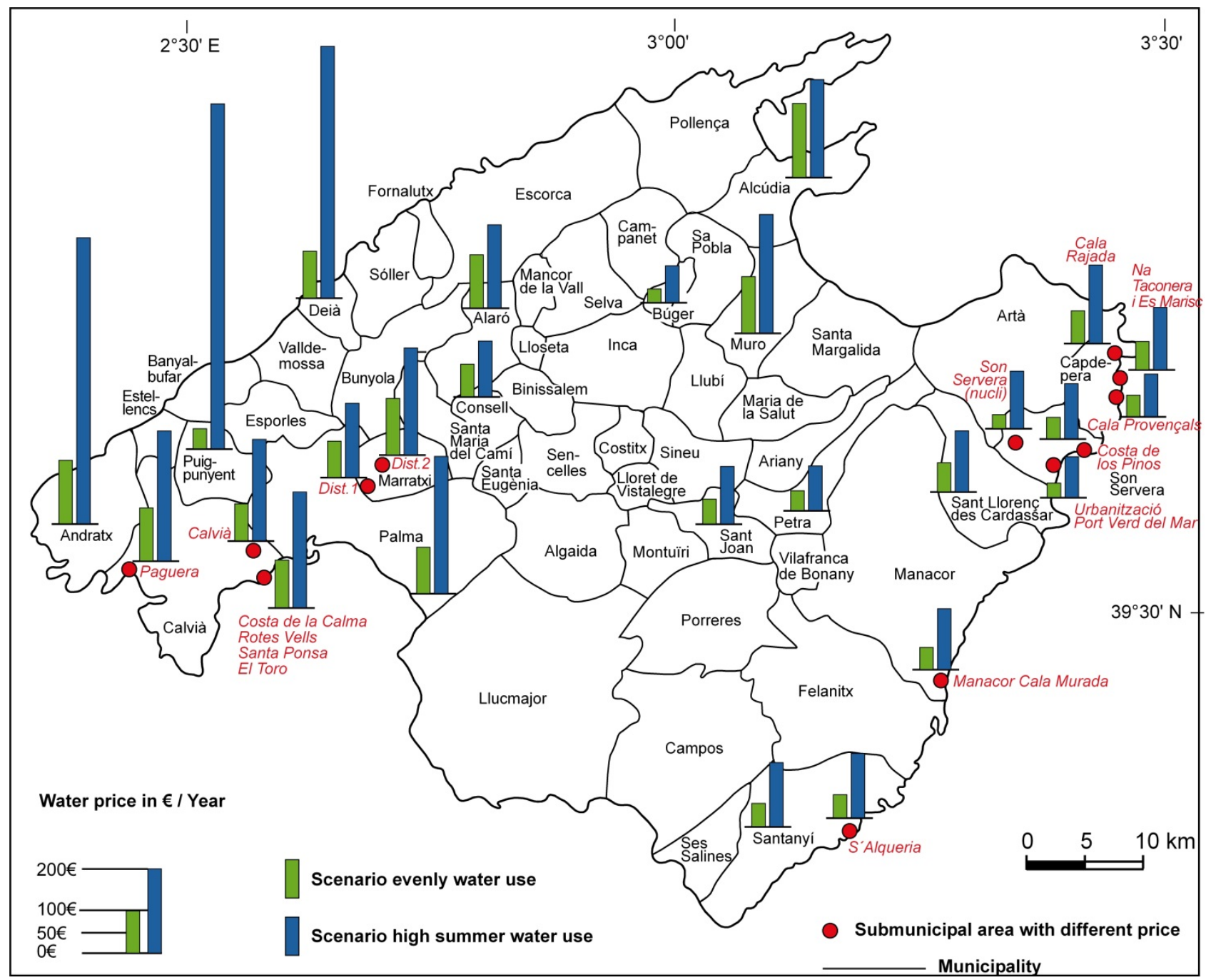

Source: authors' elaboration. Design and cartography by the authors

Table 5. Urban water prices per unit of consumption for two different use scenarios: evenly versus high summer water use

\begin{tabular}{|l|c|c|c|}
\cline { 2 - 4 } \multicolumn{1}{c|}{} & \multicolumn{3}{c|}{ Water price in Euro per cubic metre - With service and maintenance charge } \\
\cline { 2 - 4 } \multicolumn{1}{c|}{} & Mean & Standard deviation & Coefficient of variability \\
\hline $\begin{array}{l}\text { Scenario of evenly water } \\
\text { use }\end{array}$ & 0.96 & 0.46 & 0.48 \\
\hline $\begin{array}{l}\text { Scenario of high } \\
\text { summer water use }\end{array}$ & 0.98 & 0.77 & 0.78 \\
\hline
\end{tabular}


Table 5. Continues

\begin{tabular}{|l|c|c|c|}
\hline & \multicolumn{3}{|c|}{ Water price in Euro per cubic metre - Without service and maintenance charge } \\
\hline & Mean & Standard deviation & Coefficient of variability \\
\hline $\begin{array}{l}\text { Scenario of evenly water } \\
\text { use }\end{array}$ & 0.56 & 0.29 & 0.52 \\
\hline $\begin{array}{l}\text { Scenario of high } \\
\text { summer water use }\end{array}$ & 0.84 & 0.73 & 0.88 \\
\hline
\end{tabular}

Source: authors' elaboration

\section{Conclusions and outlook}

Next to an overview of urban water rate structures on the island of Mallorca, this paper's main outcome is offering a simulation, based in real consumption patterns, of the water pricing system, in Mallorca according to official pricing in 2014. The analysed data correspond to the municipalities charging the water supply cost monthly. The general trend is that prices are low: $0.56 € / \mathrm{m}^{3}$ for the low consumption scenario and $0.84 € / \mathrm{m} 3$ for the higher scenario, characteristic of extensive urban sprawl areas with Atlantic gardens and swimming pools. Further to this, block rates are so distorted that 12 out of our 28 study cases have cheaper prices, as a mean of $€ / \mathrm{m}^{3}$, in the scenario of higher water consumption. According to these results, block rate is not sending a strong price signal about the scarcity of water to customers in these municipalities or submunicipal areas.

Hypotheses are formulated as an outcome of this exploratory study of urban water rate structure, water prices for domestic end users and the institutional framework. The first hypothesis is that water prices and water rate structures are correlated with urban water consumption patterns at municipality scale as reflected in different indicators of consumption. Moreover, water prices are expected to reflect the scarcity of water resources on the island on the one hand, and the large range of urban water consumption related to the urban land use pattern on the other hand. Both developments and societal challenges are well documented in the scientific literature (Calatrava \& Garrido, 2009; García-Rubio et al., 2015). That is, one would expect that some natural and build environment patterns will be reflected in the domestic water prices that have been compiled and show, for example some correlation with tourist accommodation capacity, desalinated water urban supply or with other water supply geographical characteristics, such as dry or wetter regions or aquifers in worse or better condition on the island.

The second hypothesis that leads this process is that other explanations can be found to understand the pricing structure, related to private acquisition of rights to the water extraction and supply. The process of urban water supply and pricing is taking place in a setting that allows for myriad hidden agendas to influence the outcome of the pricing exercise. Also bureaucratic inefficiency in the definition of the tariffs progressive blocks constrains the process. 
At the national level, the framework and administrative structures in the water sector are highly decentralized, so that each of the more than eight thousand municipalities is the legal entity governing the water services in its jurisdiction. The municipality may be a service provider itself or integrate local water entities to provide services to a broader area. Public and private management models and mixtures thereof are possible. In addition to water service provision, the municipality is completely independent and in charge of tariff regulation, setting taxes and ultimately, pricing. In the autonomous communities, the Committee on Prices and the administration of the municipality are in charge of authoring prices. In some cases, only one of the two entities makes the decisions on prices (compare EEA, 2013, p. 42).

In Mallorca, most of the supply services are privatised and the concessionary enterprises demand for the pricing patterns that are established by the municipal authorities. The concessionaries are reaping the benefit of appropriation of a public good exploitation. Those authorities have not skilled personnel able to establish appropriate progressive blocks, addressed to penalize the abusive water use, within this water scarcity environment. According to the experience of the regional government technicians (among them, one of the authors of this paper), local authorities are establishing water prices according to electorate rationality. This is, not increasing water prices in order not to infuriate voters. This process is giving as a result the low prices that our study has identified and the lack of really progressive tariffs. This is why the theoretical aims of such a progressive block rate structure system are not achieved, particularly pricing to send signals and incentives for a more prudent water use to the consumers. The regional government authorities are conscious of this constraint and plan contributing to a better understanding of the tariff regulation process in order to enhance public awareness, from the local authorities to the customers.

Acknowledgments: This research has been funded by the Spanish Ministry of Economy and Competitiveness and the European Regional Development Fund (ERDF). Project title: "Crisis and restructuring of the Spanish coastal tourism areas" (CSO2015-64468-P).

Authorship statement: The authors declare no conflict of interest. A.H., M.B-S. and J.M.G. conceived and designed the research concept and data analysis; J.M.G. compiled the water prices and water rate structure for each municipal and submunicipal area; A.H., M.B-S. and J.M.G. designed the calculation scheme; A.H. and M.B-S. performed the calculations; A.H. and M.B-S. wrote the paper and J.M.G. contributed material. The manuscript was produced through contributions of all authors; all authors have given approval to the final version of the manuscript. 


\section{References}

Calatrava, J., \& Garrido, A. (2009). Trends in water pricing and markets. In M. Ramón Llamas, \& A. Garrido (Eds.), Water Policy in Spain (pp. 131-144). CRC Press.

Candela, L., Bejarano, C., Von Igel, W., \& Alonso A. (2005). Report on Majorca. In A. A. Donta, M. A. Lange, \& A. Herrmann (Eds.), Water on Mediterranean Islands: Current conditions and prospects for sustainable management (pp. 11-95). Muenster: Centre for Environmental Research University of Muenster.

Candela, L., Elorza, F. J., Jiménez-Martínez, J., \& Von Igel, W. (2012). Global change and agricultural management options for groundwater sustainability. Computers and Electronics in Agriculture, 86, 120-130. doi: 10.1016/j.compag.2011.12.012

Deyà-Tortella, T., \& Tirado, D. (2011). Hotel water consumption at a seasonal mass tourist destination. The case of the island of Mallorca. Journal of Environmental Management, 92(10), $2568-2579$.

Deyà-Tortella. T., García, C., Nilsson, W., \& Tirado, D. (2016). The effect of the water tariff structures on the water consumption in Mallorcan hotels. Water Resources Research, 52(8), 63866403.

Deyà-Tortella, B., Garcia, C., Nilsson, W., \& Tirado, D. (2017). Analysis of Water Tariff Reform on Water Consumption in Different Housing Typologies in Calvià (Mallorca). Water, 9(6), 425. doi: $10.3390 /$ w9060425

Dinarès, M., \& Saurí, D. (2015). Water consumption patterns of hotels and their response to droughts and public concerns regarding water conservation: The case of the Barcelona hotel industry during the 2007-2008 episode. Documents d'anàlisi geogràfica, 61(3), 623-649.

Dodds, R., \& Kelman, I. (2008). How Climate Change is Considered in Sustainable Tourism Policies: A Case of The Mediterranean Islands of Malta and Mallorca. Tourism Review International, 12(1), 57-70.

Domene, E., \& Saurí, D. (2006). Urbanisation and water consumption: Influencing factors in the Metropolitan Region of Barcelona. Urban Studies, 43(9), 1605-1623.

Donta, A. A., \& Lange, M. A. (2008). Water Management on Mediterranean Islands: Pressure, Recommended Policy and Management Options. In P. Koundouri (Ed.), Coping with Water Deficiency (pp. 11-44). Netherlands: Springer.

EEA, European Environment Agency (Ed.) (2013). Assessment of cost recovery through water pricing (EEA Technical report $n^{\circ}$ 16/2013). Retrieved from http://www.eea.europa.eu/publications/assessment-of-full-cost-recovery/at_download/file 
FACUA-Consumidores en Acción (Eds.) (2013). Estudio comparativo sobre las tarifas del agua en 28 ciudades. Retrieved from https://www.facua.org/es/guias/estudio-tarifas-agua2013.pdf

García-Rubio, M., Ruiz-Villaverde, A., \& González-Gómez, F. (2015). Urban Water Tariffs in Spain. What Needs to Be Done? Water, 7(4), 1456-1479. doi: 10.3390/w7041456 Retrieved from http://www.mdpi.com/2073-4441/7/4/1456/pdf

Gikas, P., \& Angelakis, A. N. (2009). Water resources management in Crete and in the Aegean Islands, with emphasis on the utilization of non-conventional water sources. Desalination, 248(1-3), 1049-1064. doi: 10.1016/j.desal.2008.10.021

Govern de Les Illes Balears (Ed.) (2012). Portal de l'Aigua de les Illes Balears. Sumministre i consum urbà d'aigua a les Illes Baleras per terme municipal. Retrieved from https: $/ /$ www. caib.es $/$ sacmicrofront/contenido.do?idsite $=259 \&$ cont $=22868$

Govern De Les Illes Balears (Ed.) (2017). BOIB (Butlletí Oficial de les Illes Balears) Retrieved from hitp://www.caib.es/eboibfront/ca

Gössling, S., Peeters, P., Hall, C.M., Ceron, J. P., Dubois, G., Lehmann, L. V., \& Scott, D. (2012). Tourism and water use: Supply, demand, and security. An international review. Tourism Management, 33(3), 1-15. doi: 10.1016/j.tourman.2011.03.015

Hanemann, W. M. (1998). Price and rate structures. In D. D. Baumann, J. Boland, \& W. M. Hanemann (Eds.), Urban water demand management and planning (pp. 137-179). New York: McGraw-Hill.

Hernández, M., Saurí, D., \& Morales, A. (2015). Auge y caída de nuevas naturalezas urbanas: plantas ornamentales y expansión turístico-residencial en Alicante. Boletín de la Asociación de Geógrafos Españoles, 68, 129-157.

Hof, A., \& Blázquez, M. (2013). The Linkages between Real Estate Tourism and Urban Sprawl in Majorca (Balearic Islands, Spain). Land, 2(2), 252-277.

Hof, A., \& Blázquez-Salom, M. (2015). Changing tourism patterns, capital accumulation, and urban water consumption in Mallorca, Spain: a sustainability fix? Journal of Sustainable Tourism, 23(5), 770-796.

Hof, A., \& Schmitt, T. (2011). Urban and tourist land use patterns and water consumption: evidence from Mallorca, Balearic islands. Land Use Policy, 28(4), 792-804. doi: 10.1016/j.landusepol.2011.01.007

Hof, A., \& Wolf, N. (2014). Estimating potential outdoor water consumption in private urban landscapes by coupling high-resolution image analysis, irrigation water needs and evaporation 
estimation in Spain. Landscape and Urban Planning, 123, 61-72. doi: 10.1016/j.landurbplan.2013.12.010.

Hof, A., Blazquez-Salom, M., Comas-Colom, M., \& Baron-Periz, A. (2014). Challenges and solutions for urban-tourist water supply on Mediterranean tourist islands: The case of Majorca, Spain. In A. Bhaduri, J. Bogardi, J. Leentvaar, \& S. Marx (Eds.), The global water system in the Anthropocene: Challenges for science and governance (pp. 125-142). Cham: Springer International Publishing.

Howe, C. W. (1998). Forms and functions of water pricing: an overview. In D. D. Baumann, J. Boland, \& W. M. Hanemann (Eds.), Urban water demand management and planning (pp. 181189). New York: McGraw-Hill.

IBESTAT (Ed.) (2012). Estadísticas: Población. Población de derecho y de hecho por isla y $\begin{array}{lllll}\text { municipio. } & \text { Censos } & 1857 & \text { a } & \text { Retrieved }\end{array}$ from https://ibestat.caib.es/ibestat/estadistiques/poblacio/censos-poblacio/evolucio-poblaciocensos/5227ae5b-957d-4ee3-92dd-1a6848690f23

Lazarova, V., Levine, B., Sack, J., Cirelli, G., Jeffrey, P., Muntau, H., Salgot, M., \& Brissaud, F. (2001). Role of water reuse for enhancing integrated water management in Europe and Mediterranean countries. Water Science \& Technology, 43(10), 25-33.

Maestu, J., \& Gómez, C.M (2010). Water uses in transition. In M. Ramón Llamas, \& A. Garrido (Eds.), Water Policy in Spain (pp. 39-48). Boca Raton: CRC Press.

Mantecón, A. (2010). Tourist modernisation and social legitimation in Spain. International Journal of Tourism Research, 12(5), 617-626. doi: 10.1002/jtr.784

March, H., \& Saurí, D. (2010). The Suburbanization of Water Scarcity in the Barcelona Metropolitan Region: Sociodemographic and Urban Changes Influencing Domestic Water Consumption. The Professional Geographer, 62(1), 32-45.

March, H., Saurí, D., \& Rico-Amorós, A. M. (2014). The end of scarcity? Water desalination as the new cornucopia for Mediterranean Spain. Journal of Hydrology, 519(part C), 2642-2651.

Masjuan, E., March, H., Domene, E., \& Saurí, D. (2008). Conflicts And Struggles Over Urban Water Cycles: The Case Of Barcelona 1880-2004. Tijdschrift voor Economische en Sociale Geografie, 99(4), 426-439.

Morán, C. (2013, August 5). La reforma del agua dará más garantías al inversor privado. Entrevista a Federico Ramos, Secretario de Estado de Medio Ambiente. Expansión, p. 17.

Morote, A. F., \& Hernández, M. (2016). Urban sprawl and its effects on water demand: A case study of Alicante, Spain. Land Use Policy, 50, 352-362. 
Morote, A.F., Saurí, D., \& Hernández, M. (2017). Residential Tourism, Swimming Pools, and Water Demand in the Western Mediterranean. The Professional Geographer, 69(1), 1-11. doi: 10.1080/00330124.2015.1135403

Murray Mas, I., Yrigoy Cadena, I., \& Blázquez-Salom, M. (2017). The role of crises in the production, destruction and restructuring of tourist spaces. The case of the Balearic Islands. Investigaciones Turísticas, 13, 1-29. doi: 10.14198/INTURI2017.13.01

Parés, M., March, H., \& Saurí, D. (2013). Atlantic Gardens in Mediterranean Climates: Understanding the Production of Suburban Natures in Barcelona. International Journal of Urban and Regional Research, 37(1), 328-347. doi: 10.1111/j.1468-2427.2012.01118.x

Rico-Amorós, A. M., Olcina-Cantos, J., \& Saurí, D. (2009). Tourist land use patterns and water demand: Evidence from the Western Mediterranean. Land Use Policy, 26(2), 493-501.

Rico-Amorós, A. M., Olcina-Cantos, J., \& Saurí, D. (2013). Beyond Megaprojects? Water Alternatives for Mass Tourism in Coastal Mediterranean Spain. Water Resources Management, 27(2), 553-565.

Rodríguez Díaz, J. A., Knox, J. W., \& Weatherhead, E. K. (2007). Competing demands for irrigation water: golf and agriculture in Spain. Irrigation and Drainage, 56(5), 541-549. doi: 10.1002/ird.317

Trillas, A. (2013). Rescate a cambio de gestión privada. Alternativas económicas, 5, 8-11.

Vidal, M., Domene, E., \& Saurí, D. (2010). Changing geographies of water-related consumption: residential swimming pools in suburban Barcelona. Area, 43 (1), 67-75. doi: 10.1111/j.14754762.2010.00961.x 